\title{
Communication Strategy for Children with Speech Delay
}

\section{Edhy Rustan}

edhy_rustan@iainpalopo.ac.id

Islamic State Institute of Palopo

\begin{abstract}
Delay in talking to children certainly has an impact on the stages of its development so that it requires a communication strategy from both parents and teachers to stimulate the child's speaking ability. This study aimed to describe the application of communication strategies and the effect of their application on children's communication skills. This research is qualitative research using a case study method involving students, parents and kindergarten teachers in Jumni City, Palopo. The results of observations and interviews were then analyzed using thematic content analysis techniques. Based on observations and interviews conducted, it was found that parents implemented various strategies, such as speaking slowly and clearly, routinely inviting talking and using hand movements. While, the teacher implements strategies to correct word pronunciation errors, invites storytelling and uses body movements. Through the application of this strategy, the child's ability to speak is getting better and the principle of two-way communication can occur where students are able to channel their desires, imagination, and emotions. Thus, it is hoped that communication strategies can be developed and implemented by parents and teachers to the fullest.
\end{abstract}

Keywords: child, communication strategy, speech delay

\section{Introduction}

Communication is any action in which information is given or received from other people regarding facts, thoughts, ideas, and feelings. Communication can be done both verbally and non-verbally (Rustan \& Subhan, 2018). Speaking is an expression of thoughts that are spoken in the form of words. Speech ability is trained since the child is still a baby with developmental stages in accordance with age. Until at the age of 5 years were the child is able to communicate well, able to understand words without stuttering (Reilly, Mckean, Morgan, \& Wake, 2015). However, in its development, it is estimated that between 5\% - 12\% of children who are 2 to 5 years' experience speech delay (Mclaughlin, 2011). Speech and language disorders are one of the causes of developmental disorders which mostly often found in children.

As a means of communication, language plays an important role in a child's life. Children with a speech delay can affect further developments, such as developments in writing and reading which result in academic success (Tomblin, Zhang, Buckwalter, \& Catts, 2000). In addition, the delay in speaking can also affect a child's ability to socialize (Sun \& Fernandes, 2014). Children become shy, have lack of confidence and lack of courage to do things, that can interfere with the child's personality development (Lipscombe, Boyd, Colemen, Fahey, Rawicki, \& Whittingham, 2016). Children who have speech delay will feel they are not accepted by their peers, will become less confident, and tend to be reluctant to do something due to fear. This can have an impact on the child's future development. Therefore, we need a communication strategy used by parents and teachers in accordance with the 
difficulties carried out by children. Parents and teachers can start by speaking slowly, using short sentences or using language symbols through special gestures and gestures.

Delay in the speech was also experienced by some 5-year-old children in the Jumni Kindergarten. Children's speaking ability is not in accordance with the stages of development where the child's ability is only limited to saying one or two words. When the child was asked to communicate, the child just repeated the question. For example, when they were asked, "what color is this?", the children then answered slowly "what color is this". Thus, the difficulty in speaking has an impact on the child's social life. Therefore, this study proposes to study the description of the application of symbolic communication strategies by parents and teachers to children and how they affect the child's acceptance.

\section{Literature Review}

The American Speech-Language Hearing Association describes speech disorders as the decrease in articulation, fluency, or sound. Meanwhile, language disorders is defined as a disorder of understanding or using oral, written, or other symbolic systems. Disorders may involve forms of language (phonology, morphology, syntax), language content (semantics), and language functions in communication (pragmatic) under any circumstances (Wallace, Berkman, Watson, Coyne-Beasley, Wood, Cullen, \& Lohr, 2015). This disorder is the most worried problem by parents when consulting a doctor.

There are two factors causing speech delay, intrinsic and extrinsic factor. Intrinsic factor covers the brain development disorder and abnormalities in speech organs. Damage in brain development and abnormalities in speech organs are one the causes of speech delay to children (Özdas, sahihli, Özdemir, \& Belgin, 2018). To be able to speak, it is necessary to coordinate the sensory and motor systems that are assisted by the hearing organ (Befi-Lopes, Cáceres-Assenço, Marques, \& Vieira, 2014). When someone hears, the air vibration enters the outer ear hole until it reaches the tympanic membrane and is transmitted to the inner ear so that the sound waves reach the sensory receptors to be transmitted to the brain. After being processed in the brain, answers then formulated in the form of articulation that is transmitted to the motor to make speech movements. Furthermore, the speech process is produced by vibrations of the vocal cords aided by the flow of air from the lungs, while sounds are formed by the movement of the lips, tongue, and palate.

Extrinsic factor is mainly caused by family and environment. The family is the first school for children so it will determine the future development of children. The problems that may occur from family factor are mother's vocabulary, socio-economic status, communication frequency in the family, family history and language used by the family (Eadie, Morgan, Ukoumunne, Eecen, Wake, \& Reilly, 2015). The frequency of communication in the family is related to a lack of attention and social motivation from the family (Tager-Flusberg \& Kasari, 2013). Likewise with communication skills, the more often parents invite children to communicate, the more pronunciation will be trained. Children are able to automatically memorize words that are repeated over and over again because they are supported by the child's mental lexicon that is still neatly arranged and structured compared to adults (Rustan \& Subhan, 2018).

Children with a speech delay can be stimulated by various communication strategies. In between routinely inviting them to speak, group intervention by including children to play with peers, by using communication media tools through applications that can be imitated by children (Agius \& Vance, 2016). For children with speech delay, communication should be 
stimulated by improvising the use of language and good communication skills, parents, and teachers use language that is short and easy to understand while using symbols or sign language and the use of media that produces sound (Tager-Flusberg \& Kasari, 2013). This improvising can train the sensory and motor skills of children without making children confused (Newman, Supalla, Fernandez, Newport, \& Bavelier, 2015). However, it should be kept in mind that in following up on delays in children's speech delay, it is necessary to study the needs of the child so that the intervention is given in accordance with the needs or problems experienced by that child. Therefore, it is important for parents to consult with a doctor or psychologist about the child's disorder (Jacqueline, 2016).

In addition to parents, the role of the teacher can also be maximized in stimulating students with speech impediments. The teacher's role can be illustrated in the teaching and learning process with students who are active in communicating. Similar to parents, teachers can also use symbolic communication strategies through the use of conversational language, training children to communicate through the method of storytelling through the method of connecting words.

The right communication strategy can be used and able to speak with the ability to speak, vocabulary ago and words that match their development. In addition, the application of communication strategies also focuses on the mental condition of children so that children become motivated to be able to communicate with family, peers, and people around them

\section{Methods}

This research is a qualitative study using a case study method. This research was conducted in the city of Palopo, precisely at Jumni Kindergarten. While, the subjects in this study were students who experienced speech delay totaling 6 people by including their parents along with the Jumni Kindergarten teaching team. Data collection began from January 8 to January 13, 2019. Researchers participated in activities at school ranging from children who came, during the learning process until the children returned home. Researchers observed how the communication strategies used by parents and teachers in practicing children's speaking skills. Interviews were conducted in the teacher's office or in the classroom when learning was taking place. Interview results were recorded and stored using a cellphone and were then analyzed. In conducting interviews, researchers asked about how the parents of students and teachers stimulated the children to speak and how the way parents and teachers speak influenced the ability to communicate with children of speech delay. Participants were told that they could reject any questions and could stop the interview at any time. Interview results were recorded and stored using a cellphone and then analyzed. Then, the data were analyzed using thematic analysis techniques consisting of two themes namely (1) a description of the application of communication strategies by parents and teachers; and (2) the effect of applying the communication strategy to the child's acceptance.

\section{Findings \\ Application of communication strategies}

Speech delay is a condition where the child has a speech delay that is not in accordance with the stages of its development. This condition certainly makes it difficult for children to communicate every day so that an appropriate communication strategy is needed. 
As the closest person and have a longer time with the child, parents have an important role in stimulating the child's speaking ability. There are several strategies taken by parents of kindergarten students Jumni, including:

Speak slowly and clearly, based on the results of the interview, the communication strategies used by parents of children with speech delays were almost the same. All parents applied soft talk with clear articulation that was apparent when they communicated with each other. As one of the students' parents expressed:

"to speak with my child who experienced speech delay I spoke softly, the words were clearly expressed". (SA, Personal Communication, 2019).

Routinely invite to talk, routine strategies to invite children to speak were expressed by 3 parents of students. For busy parents, time to gather with family was so lacking that communication became less and had an impact on speech delays that occur in children. So to stimulate it:

"parents spend more time talking to children" (AM, Personal Communication, 2019). However, it is different from what was stated by the SA that :

"I have a hard time dividing so that children are better trained to speak I prefer to use the application on the cell phone to train children to talk". (SA, Personal Communication, 2019).

This strategy was chosen because this media was more attractive to children so that children were more motivated. Some chose to bring their children more often to gather with their friends so that children learned to talk through their friends.

Using hand movements, hand movements were needed to clarify the meaning of the words spoken so that the child becomes easier to understand. He said:

"My son understands more when using his hands than just talking". (RN, Personal Communication, 2019).

Furthermore, the environment where children learn in school needs to also be taken into account since it also affects children's speech delay. In this case, the teacher stimulates the child's speaking ability through modification of the existing curriculum. The strategies undertaken by Jumni Kindergarten teachers are as follows:

Improve pronunciation, often children mistakenly pronounced words like "eat" to "ma ... ma" or "mam". When the child uttered words that were not appropriate then the teacher tried to understand what the child was saying and invited the child to say the correct word repeatedly until the child could pronounce the word correctly. This was reinforced from the results of interviews with the teacher that:

"children here are often wrong in saying the words so that when the teacher hears the word the teacher teaches the child how to pronounce it right until the child is proficient in saying it". (MM, Personal Communication, 2019).

Using symbolic movements, with a variety of students' characteristics, more efforts are needed so that all students can follow the learning process. One of the communication strategies used at school was to speak slowly while using body movements. From observations, it is known that body movements could be in the form of hand, foot or body movements as a whole according to the context of the sentence delivered. As stated :

"when speaking with students of speech delay, we must slowly and pronounce it with clear articulation while moving our hands" (AS, Personal Communication, 2019).

For example, inviting to read a prayer before eating,

"while inviting in a quiet and clear voice, I raise my hand like I'm praying". (MM, Personal Communication, 2019). 
Inviting storytelling, for teachers, speaking routines are implemented through storytelling activities in the classroom.

"Every child gets a chance to speak but is preferred for children who experience delays in speaking". (NF, Personal Communication, 2019).

"Even this strategy was applied in the form of word conjunctions". (MM, Personal Communication, 2019).

Also, "speech delay children are given special guidance such as the practice of saying words". (AN, Personal Communication, 2019).

In this guidance, every day children get to practice saying the words and sentences according to the level of communication skills of children through the method of telling stories with the teacher.

\section{The effect of the application of communication strategies on the acceptance of children}

The implementation of communication strategies for children of speech delay is expected to stimulate children's speaking abilities and help children communicate. This is reinforced by the results of the interview,

"the implementation of word-playing games and storytelling in the class encourages students to speak so that the child is indirectly trained". (AI, Personal Communication, 2019).

It was further revealed that:

"through the application of strategies in schools students who used to have difficulty speaking are now slowly beginning to be able to speak even though they are stuttering". (MM, Personal Communication, 2019).

\section{Discussion}

The results showed that the communication strategies used by parents and teachers were almost the same, namely using slow speech, clear articulation, routinely invited to communicate, correcting pronunciation errors and using hand gestures as symbolization. The implementation of this communication strategy can improve children's speaking ability and the achievement of the principle of two-way communication between children's speech delay with those around them through the implementation of communication strategies as well as those carried out by parents and teachers. The results of this study are in line with research conducted by Wodka, Mathy and Kalb (2013) which suggests that increasing the frequency of communication between children and parents will increase children's communication skills, but the communication must be accompanied by the use of clear language and not confuse children.

The use of mobile applications as a teaching strategy for children routinely was in line with the findings of Wodka, Mathy and Kalb (2013) mentioning that parents can use technology to practice children's speech skills such as applications on Android or television. That is because in these media children are more focused because the presentations are more interesting and easier to imitate. In addition, the application of hand gesture strategies that help children in communicating was also mentioned in the research conducted by Wodka, Mathy and Kalb (2013) that revealed that the use of symbols can facilitate children to 
understand and imitate, so that when communicating with others, these movements can be easily applied. Thus, the deadlock in communicating with a children's speech delay can be overcome.

\section{Conclusion}

Delay in speech is characterized by the characteristics of the child's inability to understand and to respond to peers, parents or adults around him, being more silent, being unable to form simple sentences, being unable to answer the questions correctly (when asked something, the child repeats the question given). To overcome the delay in speaking, it requires an appropriate communication strategy from parents and teachers. This can be done by speaking slowly and clearly, routinely talking to the children, correcting mistakes in pronunciation and using hand movements as a symbol of what is being said. It is hoped that communication strategies will be further developed to help speech delay children improve their speaking abilities

\section{References}

Agius, M. M., \& Vance, M. (2016). A comparison of PECS and IPad to teach requesting to pre-schoolers with autistic spectrum disorders. AAC: Augmentative and Alternative Communication, 32(1), 58-68. Retrieve from https://doi.org/10.3109/07434618.2015.1108363.

Befi-Lopes, D. M., Cáceres-Assenço, A. M., Marques, S. F., \& Vieira, M. (2014). School-age children with specific language impairment produce more speech disfluencies than their peers. CoDAS, 26(6), 439-443. Retrieve from https://doi.org/10.1590/2317$1782 / 20142014095$.

Eadie, P., Morgan, A., Ukoumunne, O. C., Eecen, K. T., Wake, M., \& Reilly, S. (2015). Speech sound disorder at 4 years: Prevalence, comorbidities, and predictors in a community cohort of children. Developmental Medicine and Child Neurology, 57(6), 578-584. Retrieve from https://doi.org/10.1111/dmcn.12635.

Jacqueline, B. W. (2016). Articulation and Phonology in Speech Sound Disorders: A Clinical Focus. Instructor's Resource Manual to Accompany, (5).

Lipscombe, B., Boyd, R. N., Colemen, A., Fahey, M., Rawicki, B., \& Whittingham, K. (2016). Does early communication mediate the relationship between motor ability and social function in children with cerebral palsy? Research in Developmental Disabilities, 53-54, 279-286. Retrieve from https://doi.org/10.1016/j.ridd.2016.02.013.

Mclaughlin, M. R. (2011). Speech and language delay in children. American Family Physician, 83(10), 1183-1188.

Newman, A. J., Supalla, T., Fernandez, N., Newport, E. L., \& Bavelier, D. (2015). Neural systems supporting linguistic structure, linguistic experience, and symbolic communication in sign language and gesture. Proceedings of the National Academy of Sciences, 112(37), 11684-11689. Retrieve from https://doi.org/10.1073/pnas.1510527112.

Özdaş, T., Şahli, A. S., Özdemir, B. S., \& Belgin, E. (2018). Comparison of anxiety and child-care education characteristics of mothers who have children with or without speech delays. Brazilian Journal of Otorhinolaryngology. Retrieve from https://doi.org/10.1016/j.bjorl.2017.12.004. 
Reilly, S., Mckean, C., Morgan, A., \& Wake, M. (2015). Identifying and managing common childhood language. $B M J$, 2318(1), 1-10. Retrieve from https://doi.org/10.1136/bmj.h2318.

Rustan, E., \& Subhan. (2018). Komunikasi verbal anak pesisir usia 7-8 tahun pada transakasi penjualan produk kebudayaan dengan turis mancanegara. JPUD-Jurnal Pendidikan Usia Dini, 12(1), 12-28. Retrieve from https://doi.org/10.21009/JPUD.121 02.

Sun, I. Y. I., \& Fernandes, F. D. M. (2014). Communication difficulties perceived by parents of children with developmental disorders. CoDAS, 26(4), 270-275. Retrieve from https://doi.org/10.1590/2317-1782/201420130024.

Tager-Flusberg, H., \& Kasari, C. (2013). Minimally verbal school-aged children with autism spectrum disorder: The neglected end of the spectrum. Autism Research, 6(6), 468-478. Retrieve from https://doi.org/10.1002/aur.1329.

Tomblin, J. B., Zhang, X., Buckwalter, P., \& Catts, H. (2000). The association of reading disability, behavioral disorders, and language impairment among second-grade children. Journal Child Psychology Psychiatry, 41(4), 473-482.

Wallace, I. F., Berkman, N. D., Watson, L. R., Coyne-Beasley, T., Wood, C. T., Cullen, K., $\&$ Lohr, K. N. (2015). Screening for speech and language delay in children 5 years old and younger: A systematic review. Pediatrics, 136(2), 448-462. Retrieve from https://doi.org/10.1542/peds.2014-3889.

Wodka, E. L., Mathy, P., \& Kalb, L. (2013). Predictors of phrase and fluent speech in children with autism and severe language delay. Pediatrics, 131(4), 1128-1134. Retrieve from https://doi.org/10.1542/peds.2012-2221. 